\title{
Relacje małych firm technologicznych (MFT) z innymi przedsiębiorstwami
}

https://doi.org/10.33141/po.2005.10.05

\section{Marek Martin}

\section{Wprowadzenie}

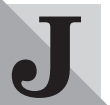
ednym ze sposobów przezwyciężania wewnętrznych ograniczeń rozwoju, w tym ograniczeń związanych z niedostatkiem wewnętrznych zasobów małych firm technologicznych ${ }^{1)}$ (MFT), w ramach szerzej rozumianych strategicznych uwarunkowań rozwoju MFT, jest nawiązywanie współpracy i budowanie powiązań z innymi, w szczególności większymi podmiotami gospodarczymi ${ }^{2}$. Alternatywą dla konsekwentnego budowania często złożonych i wielopoziomowych oddziaływań pomiędzy innowacyjnymi podmiotami gospodarczymi a otoczeniem jest strategia oparta na czystej konkurencji, prowadząca do izolacji i w konsekwencji ograniczenia możliwości rozwoju małej firmy. W procesie interakcji pomiędzy małymi i dużymi firmami duże podmioty gospodarcze są ważnym źródłem wykwalifikowanych pracowników, w tym również o profilu technicznym. Relacje te w przypadku luźnych form współpracy mogą ograniczać się do prostych kontaktów handlowych, w najbardziej zaawansowanych formach powiązań mogą prowadzić do przejęcia MFT przez duży podmiot gospodarczy.

\section{Formy powiązań MFT z innymi przedsiębiorstwami}

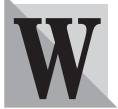

ujęciu teoretycznym współpraca pomiędzy MFT a innymi, w szczególności większymi, podmiotami gospodarczymi poprzez wykorzystanie kombinacji unikatowego know-how reprezentowanego przez MFT z zasobami dużych podmiotów gospodarczych powinna przyczynić się do wytworzenia wzajemnie korzystnych efektów synergicznych ${ }^{3)}$. Efekty te wynikają z pewnych silnych i słabych stron małych i dużych podmiotów gospodarczych w dziedzinie innowacyjności. Źródła przewag dużych podmiotów gospodarczych są w głównej mierze natury materialnej, należą do nich przede wszystkim: wielkość zasobów finansowych, rozbudowane sieci dystrybucji, wysoka skala nakładów na B+R. Przewagi małych podmiotów gospodarczych w dziedzinie innowacyjności są w głównej mierze natury behawioralnej, należą do nich: otwartość umysłu, duch przedsiębiorczości, elastyczność i łatwość dostosowywania się do zmieniającego otoczenia. Teoretyczne rozważania mogą prowadzić do wniosku, że duże firmy w przypadku umiejęt-
Przegląd Organizacji, Nr 10 (789), 2005, ss. 24-26 www.przegladorganizacji.pl Towarzystwo Naukowe Organizacji i Kierownictwa (TNOiK) nego połączenia przewag materialnych z behawioralnymi mogą stać się „potężną siłą w dziedzinie innowacyjności" ${ }^{4}$. Działanie odwrotne, tzn. wykorzystanie przez małe firmy źródeł przewag konkurencyjnych dużych podmiotów gospodarczych, wydaje się mało prawdopodobne. Sytuacja ta może skutkować wystąpieniem pewnych przewag konkurencyjnych i lepszej pozycji negocjacyjnej dużych firm w relacji do MFT w przypadku podejmowania współpracy. Obserwacja prób adaptacji i wykorzystania przez duże podmioty gospodarcze źródeł przewag konkurencyjnych właściwych podmiotom mniejszej wielkości wskazuje jednak na występowanie $\mathrm{w}$ tym zakresie dużych obiektywnych trudności. Zdaniem R. Rothwella wiele dużych amerykańskich firm podejmowało próby osiagnięcia tej kombinacji poprzez wdrażanie różnorodnych technik pobudzania wewnętrznej przedsiębiorczości. W przypadku większości z nich osiagnnięto jedynie ograniczone rezultaty. Te czynniki moga, przynajmniej w pewnym stopniu, wyjaśnić, dlaczego niektóre duże firmy amerykańskie rozpoczęły aktywne poszukiwanie małych innowacyjnych partnerów w celu tworzenia nowych techniczno-rynkowych (technomarket) kombinacji opartych na wykorzystaniu nowych technologii ${ }^{5}$. Wzajemnie oddziaływania pomiędzy MFT i większymi podmiotami gospodarczymi mogą skutkować wzmocnieniem pozycji konkurencyjnej współpracujących podmiotów gospodarczych ${ }^{6)}$, jak i przyczynić się do wzmocnienia potencjału gospodarczego i tempa rozwoju regionu ${ }^{7}$. Współpraca między MFT i dużymi przedsiębiorstwami jest nie tylko wzajemnie korzystna, ale w wielu przypadkach wręcz niezbędna, stajac sa warunkiem ich przetrwania, jak pisze R. Rothwell: „[...] dla przykładu firmy zajmujące się nowoczesnymi procesami produkcyjnymi dużej skali (large scale process industries) nie sa w stanie efektywnie funkcjonować bez szerokich ram współpracy z małymi podmiotami w dziedzinie podwykonawstwa"8). W przypadku dużych podmiotów gospodarczych podstawowymi korzyściami ze współpracy z MFT są również możliwości monitorowania rozwoju nowatorskich technologii, które są rozwijane w MFT bez konieczności ponoszenia kosztów wewnątrz własnej organizacji. Ponadto duże firmy mają możliwość lepszego poznania partnera, prawidłowej oceny umiejętności organizacyjnych, przedsiębiorczości i potencjału technologicznego przedsiębiorcy-właściciela 
Tab. 1. Współpraca MFT działających w obszarze aglomeracji łódzkiej z innymi przedsiębiorstwami

\begin{tabular}{|c|c|c|c|c|}
\hline $\begin{array}{c}\text { Wielkość } \\
\text { firmy }\end{array}$ & Rodzaj firmy & $\begin{array}{c}\text { \% firm } \\
\text { współpracujących } \\
\text { systematycznie }\end{array}$ & $\begin{array}{l}\text { \% firm współpracujących } \\
\text { systematycznie w sposób } \\
\text { formalny }\end{array}$ & $\begin{array}{c}\% \text { firm } \\
\text { współpracujących } \\
\text { sporadycznie }\end{array}$ \\
\hline \multirow{3}{*}{ Mikro } & Firmy lokalne & 57,8 & 37,8 & 33,3 \\
\hline & Firmy krajowe & 44,4 & 31,1 & 33,3 \\
\hline & Firmy międzynarodowe & 8,9 & 8,9 & 6,7 \\
\hline \multirow{3}{*}{ Małe } & Firmy lokalne & 57,8 & 42,2 & 37,8 \\
\hline & Firmy krajowe & 91,1 & 68,9 & 44,4 \\
\hline & Firmy międzynarodowe & 13,3 & 8,9 & 8,9 \\
\hline \multirow{3}{*}{ Średnie } & Firmy lokalne & 46,7 & 33,3 & 35,6 \\
\hline & Firmy krajowe & 100,0 & 68,9 & 42,2 \\
\hline & Firmy międzynarodowe & 26,7 & 17,8 & 15,6 \\
\hline \multirow{3}{*}{ Duże } & Firmy lokalne & 17,8 & 15,6 & 22,2 \\
\hline & Firmy krajowe & 44,4 & 40,0 & 31,1 \\
\hline & Firmy międzynarodowe & 35,6 & 33,3 & 11,1 \\
\hline
\end{tabular}

Źródło: opracowanie własne na podstawie badań 45 MFT działających w obszarze aglomeracji łódzkiej.

MFT. W znacznym stopniu zwiększa to możliwość oceny stopnia ryzyka i potencjalnych korzyści wynikajacych z ewentualnych inwestycji kapitałowych w MFT.

Badacze zajmujący się problematyką współpracy MFT z dużymi podmiotami gospodarczymi wskazują na występowanie niekorzystnych, zarówno z punktu widzenia firmy, jak i całej gospodarki narodowej zjawisk związanych z przejęciem dynamicznych MFT przez duże firmy. Wykupienie małego podmiotu przez inwestora strategicznego wydaje się mieć niekorzystny wpływ na tempo rozwoju i wyniki finansowe MFT. Problem te został szczególnie wyraźnie udokumentowany empirycznie na gruncie gospodarki szwedzkiej, gdzie wyjątkowo często w porównaniu z innymi krajami europejskimi wystepuje zjawisko przejmowania MFT przez duże podmioty gospodarcze. Wyniki prac O. Granstranda i S. Sjolandera') wskazują, że przejęcie MFT jest z reguły niekorzystne dla jej dalszego rozwoju, w tym również zdolności do tworzenia nowych miejsc pracy. Nieco mniej kategoryczne stwierdzenia można znaleźć $\mathrm{w}$ pracach badaczy brytyjskich; A. Cosh i A. Hughes ${ }^{10)}$ są zdania, że nie można wskazać korzystnych, zarówno dla MFT, jak i gospodarki narodowej, efektów przejęcia MFT przez dużą firmę.

\section{Relacje MFT z innymi przedsiębiorstwami w regionie łódzkim w świetle badań empirycznych}

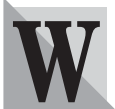

dalszej części opracowania przedstawiono wyniki badań empirycznych MFT działających w regionie łódzkim dotyczących skali i zakresu współpracy tych firm z innymi przedsiębiorstwa$\mathrm{mi}$, w tym z dużymi podmiotami gospodarczymi.

Lokalne MFT utrzymują najintensywniejszą współpracę z krajowymi podmiotami średniej wielkości zlokalizowanymi poza regionem łódzkim, $100 \%$ ba- danych firm utrzymuje współpracę z tymi podmiotami. W przypadku $68,9 \%$ z nich jest to współpraca formalna (patrz tabela 1). Nieznacznie mniej intensywna jest współpraca badanych MFT z małymi firmami krajowymi zlokalizowanymi poza regionem - 91,1\% badanych firm utrzymuje z nimi współpracę, w przypadku $68,9 \%$ jest to współpraca formalna. Wyraźnie maleje intensywność współpracy badanych MFT z lokalnymi podmiotami gospodarczymi wraz ze wzrostem ich wielkości. Jedynie 17,8\% firm współpracuje systematycznie z dużymi lokalnymi podmiotami, $15,6 \%$ w sposób formalny. W przypadku średnich firm lokalnych wskaźnik ten wynosi odpowiednio 46,7\% i 33,3\%, w grupie małych lokalnych firm rośnie do odpowiednio $57,8 \%$ i $42,2 \%$. Generalnie rzecz ujmując, badane MFT najmniej intensywnie współpracuja z firmami międzynarodowymi, zauważalna jest jednak silna tendencja do zwiększania intensywności współpracy wraz ze wzrostem wielkości partnera. Na podkreślenie zasługuje fakt, że MFT około dwa razy częściej współpracują z dużymi firmami międzynarodowymi w porównaniu z dużymi firmami lokalnymi. Niski poziom współpracy badanych firm z dużymi firmami lokalnymi może wynikać z obiektywnie niewielkiej liczby dużych krajowych podmiotów w regionie, będących potencjalnymi partnerami do współpracy z MFT. Taki stan rzeczy może w istotnym stopniu ograniczać możliwości rozwojowe lokalnych MFT. Generalnie można zauważyć pewną prawidłowość polegającą na tym, że wraz ze wzrostem odległości, jaka dzieli MFT od firm współpracujących (region, kraj, zagranica) rośnie średnia wielkość przedsiębiorstwa, z którym utrzymywana jest współpraca, i odwrotnie, wraz ze zmniejszaniem dystansu, jaki dzieli MFT od firmy współpracującej, rośnie częstotliwość współpracy z firmami mniejszymi.

Podstawowym obszarem współpracy badanych MFT z innymi firmami jest (patrz tablica 2) produk- 
Tab. 2. Zakres współpracy badanych MFT z innymi przedsiębiorstwami

\begin{tabular}{|l|c|c|c|c|}
\hline Zakres współpracy z innymi firmami & $\begin{array}{c}\text { Średnia } \\
\text { wskazań* }\end{array}$ & $\begin{array}{c}\text { Mediana } \\
\text { wskazań }\end{array}$ & $\begin{array}{c}\text { \% firm } \\
\text { korzystających } \\
\text { zormy współpracy*** }\end{array}$ & $\begin{array}{c}\text { \% firm, dla których } \\
\text { ma ona istotne } \\
\text { znaczenie*** }\end{array}$ \\
\hline Produkcja / kooperacja / podwykonawstwo & 4,2 & 5 & 95,0 & 67,8 \\
\hline Dystrybucja / marketing / sprzedaż & 4,1 & 5 & 94,6 & 65,0 \\
\hline Wymiana informacji & 2,9 & 3 & 60,0 & 26,7 \\
\hline Działalność innowacyjna & 2,7 & 2 & 57,8 & 24,4 \\
\hline Inne & 1,1 & 1 & 2,2 & 2,2 \\
\hline
\end{tabular}

* średnia ocena odpowiedzi firm w skali 7-stopniowej (1 - bez znaczenia, 2 - bardzo mało znaczenie, 3 - małe znaczenie, 4 - średnie znaczenie, 5 - duże znaczenie, 6 - bardzo duże znaczenie, 7 - podstawowe znaczenie); ** obejmuje oceny od 2 do $7 \mathrm{w}$ skali 7 -stopniowej; *** obejmuje oceny od 5 do $7 \mathrm{w}$ skali 7 -stopniowej

Źródło: opracowanie własne.

cja (dla 67,8\% firm ta forma współpracy ma istotne znaczenie) i dystrybucja/sprzedaż (65\% wskazań silnych $\left.{ }^{11)}\right)$. Wymiana informacji stanowi przedmiot współpracy z innymi firmami dla 60\% MFT, w przypadku $26,7 \%$ ma ona znaczenie istotne ${ }^{12)}$. Jedynie $57,8 \%$ badanych firm współpracuje $\mathrm{z}$ innymi podmiotami w zakresie działalności innowacyjnej, dla 24,4\% firm współpraca ta ma istotne znaczenie. W świetle uzyskanych wyników inne obszary współpracy nie mają praktycznego znaczenie dla badanych firm.

Podstawowe korzyści ze współpracy z innymi przedsiębiorstwami to: dostęp do nowych rynków zbytu (istotne znaczenie dla $46,7 \%$ firm) i poprawa stabilności firmy (istotne dla 35,6\% firm). Współpraca $\mathrm{z}$ innymi podmiotami w zakresie kreowania nowych produktów i technologii przynosi istotne korzyści jedynie $24,6 \%$ firm. Podstawową bariera w rozwijaniu współpracy z innymi podmiotami jest brak tradycji współpracy i wzajemna nieufność między przedsiębiorcami (po około $40 \%$ wskazań silnych). Zdecydowanie dominuje postrzeganie innego przedsiębiorcy jako konkurenta, a nie potencjalnego partnera do współpracy. Brak miejsc i okazji do nawiązywania współpracy oraz wysokie koszty współpracy stanowią istotną barierę dla jedynie 11,1\% badanych MFT.

\section{Zakończenie}

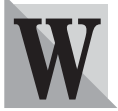

spółdziałanie z większymi podmiotami jest w oczywisty sposób warunkowane istnieniem potencjalnych partnerów do współpracy. Analiza uwarunkowań funkcjonowania rodzimych MFT pozwala na stwierdzenie, że ich relacje z większymi podmiotami gospodarczymi w zdecydowanej większości ograniczają się do typowych relacji producent-klient. Duzi producenci wyrobów technologicznych po przejęciu przez kapitał zagraniczny wykazują minimalne zainteresowanie rodzimym $\mathrm{B}+\mathrm{R}$, wykorzystujac przeniesione do Polski, a wypracowane w ośrodkach badawczo-rozwojowych zlokalizowanych w wybranych krajach wysoko rozwiniętych gotowe rozwiązania technologiczne. Monopole państwowe (lub państwowo-prywatne), do których można zaliczyć między innymi: energetykę, telekomunikację i służbę zdrowia sa dla wielu lokalnych MFT jedynymi potencjalnymi dużymi klientami i partnerami do współpracy.
Z uwagi na pewne specyficzne zachowania tych podmiotów związane w głównej mierze z brakiem rzeczywistej motywacji proinnowacyjnej, większość potencjalnych form współpracy jest obiektywnie niemożliwa do zrealizowania, skutecznie ograniczając tym samym możliwości rozwojowe rodzimych MFT.

dr Marek Martin

Katedra Ekonomii

Politechnika Łódzka

\section{PRZYPISY}

1) MFT definiowane są jako małe i średnie firmy, które: • działają w sektorach zaawansowanych technologii (zgodnie z klasyfikacją sektorów zaawansowanych technologii przyjętą przez OECD), - charakteryzują się poziomem nakładów na $B+R$ powyżej $3,5 \%$ wartości sprzedaży w danym roku, $\bullet$ posiadają stałe związki z instytucjami zaplecza $\mathrm{B}+\mathrm{R}$, $\bullet$ koncentrują się na produktach o wysokim stopniu nowości.

2) Patrz: M. MARTIN, Strategiczne uwarunkowania rozwoju matych firm technologicznych, „Ekonomika i Organizacja Przedsiębiorstwa”, nr 2, 2005.

3) Por. J.P. SEGERS, Strategic Partnering Between New Technology Based Firms and Large Established Firms in the Biotechnology and Microelectronics Industries in Belgium, „Small Business Economics”, vol. 5, 1993, s. 271-281.

4) Patrz: R. ROTHWELL, SMFs, Inter-firm Relationships and Technological Change, „Entrepreneurship \& Regional Development", vol. 1, 1989, s. 279.

5) Ibidem, s. 280.

6) Patrz: M. NIEDERKOFLER, The Evolution of Strategic Alliances: Opportunities for Managerial Influence, „Journal of Business Venturing”, vol. 6, 1991, s. 237-257.

7) Patrz: R. DONCKLES, J.P. SEGERS, New Technology Based Firms and Creation of Regional Growth Potential, „Small Business Economics”, vol. 2, 1990, s. 33-44.

8) Por. R. ROTHWELL, SMFs, Inter-firm..., op.cit, s. 276.

9) Patrz: O. GRANSTRAND, S. SJOLANDER, The Acquisition of Technology and Small Firm by Large Firms, „Journal of Economic Behavior and Organization”, vol. 13, 1990, s. 367-386.

10) Patrz: A. COSH, A. HUGHES, Acquisition Activity in Small Business Sector, [w:] A. HUGHES, D.J. STOREY (ed.), Finance and the Small Firm, Routledge, London 1994 , s. $284-315$.

11) Obejmuje oceny od 5 do $7 \mathrm{w}$ skali 7 -stopniowej.

12) Obejmuje oceny od 5 do $7 \mathrm{w}$ skali 7 -stopniowej. 